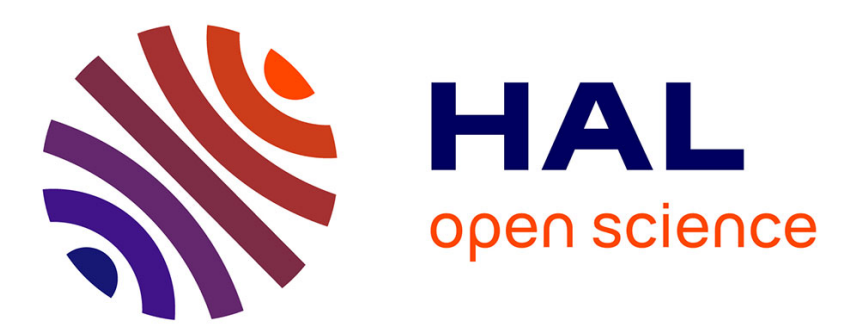

\title{
Traveling Possible Worlds in Graphic Narratives: the Example of Watchmen (Alan Moore et Dave Gibbons)
}

Clotilde Thouret

\section{To cite this version:}

Clotilde Thouret. Traveling Possible Worlds in Graphic Narratives: the Example of Watchmen (Alan Moore et Dave Gibbons). Neohelicon, 2013, 40 (2), pp.461-474. 10.1007/s11059-013-0205-x . hal02903439

\section{HAL Id: hal-02903439 \\ https://hal.univ-lorraine.fr/hal-02903439}

Submitted on 21 Jul 2020

HAL is a multi-disciplinary open access archive for the deposit and dissemination of scientific research documents, whether they are published or not. The documents may come from teaching and research institutions in France or abroad, or from public or private research centers.
L'archive ouverte pluridisciplinaire HAL, est destinée au dépôt et à la diffusion de documents scientifiques de niveau recherche, publiés ou non, émanant des établissements d'enseignement et de recherche français ou étrangers, des laboratoires publics ou privés. 


\title{
Clotilde Thouret (Université Paris-Sorbonne)
}

\author{
Traveling Possible Worlds in Graphic Narratives. \\ The Example of Watchmen (Alan Moore and Dave Gibbons)
}

\section{Why we should watch the Watchmen}

Juvenal invites us to do it in his Satires and the well known interrogation is graffitied on New York walls in the comic of Moore and Gibbons ("Quis custodiet ipsos custodes?", "Who watches the watchmen?"). But the latin poet or the New Yorkers angry at masked heroes certainly didn't have in mind questions about fictional worlds - or maybe they did. Nevertheless, Watchmen is a very helpful work to observe how a reader enters the fictional worlds in a comic book, what relation is built between them, and what consequences the reader's travels from one world to another can have in terms of effect and meaning of the graphic narrative. As a quick summary will point out, this classic graphic novel joins together different fictional worlds, intertwining many narratives of different ontological status, and actualizing a passage of the superhero from fiction to reality. This last characteristic gives a reflexive dimension to the whole story and determines the way the reader relates to it.

Watchmen is a long graphic novel of four hundred pages, which compose the twelve chapters of the book ${ }^{1}$. The action is mainly set in the United States, in New York in particular, and the story develops during the year of 1985, while the world is being under the threat of a nuclear apocalypse. We follow the lives of six main characters, who are superheroes, some of whom are retired, some not (fig. 1).

Only one of them have superpowers, Jon Osterman, who is known as Dr Manhattan. He was a scientist quantum physics; in 1959, he was trapped in a machine in which he literally exploded in atoms, but he recomposed himself and since then he has power over matter. He then became, among other things, the military shield of the US, and their most powerful weapon. Thanks to him, the United States won the Vietnam war. As a consequence Nixon changed the Constitution to get elected a third time, in 1976, and was elected again in 1980 and 1984.

The other characters are more or less like Batman, which mean they are normal people in great physic condition and using sophisticated weapons. But there is one, major, difference: they became superheroes because they read and liked superhero comics, and then copied the characters. In the fictional world of Watchmen, superhero comics exist - even if they are out of fashion - and superheroes really and literally left fiction for reality. In this respect, something has to be mentioned: for us, actual comics readers, each of the main characters of the story is like a doppelgänger of a hero we've read adventures of. For example, Daniel Dreiberg aka Nite Owl is very much like Batman; Dr Manhattan is another Superman but his depressed meditations about the world give him resemblance with the Silver Surfer as well. We could say they are like precipitates of real superhero characters ${ }^{2}$.

The storyline can be summarized as follows, the plot being also a pretext to tell the life of the different superheroes: as the tension between the United States and the USSR increases

\footnotetext{
1 Watchmen is initially a twelve-issue comic book series, published by DC Comics during 1986 and 1987, and has been subsequently reprinted in collected form. It was created by writer Alan Moore, artist Dave Gibbons and colourist John Higgins.

Obviously, this idea plays with, and shows at the same time, the transfictionality of superhero characters. There is "transfictionality" when two texts (movies, comic books, etc.) or more, by the same author or not, refer to same fiction, through the revival of a character, of the same fictional universe, through the sequel or continuation of a story; for example: the first sequel of Don Quijote, W. S. Baring-Gould's Sherlock Holmes of Baker Street, etc. (Saint-Gelais 2011).
} 
and as the war is about to start, the Crimebusters vigilantes ${ }^{3}$ seem to be cursed, or maybe someone is trying to exterminate them: The Comedian gets killed; a murder is attempted on Ozymandias; after public revelations about people who got cancer because they have lived near Dr Manhattan, he gives up his interest in the human race and its nonsense, and leaves for Mars; Rorschach, who, despite of the law forbidding costumed heroes, never stopped being one, is arrested. In fact, all this is part of Adrian Veidt's plan. Veidt used to be the superhero known as Ozymandias, the smartest and richest man on earth; he pretended to retire, but it was to save the world: with scientists and artists he invented a horrific creature, which he sends to New York killing thousands of people; facing this new threat, the US and the USSR decide to unite and a new world of peace begins, that Veidt sees as a utopia or, more to the point, his utopia.

All these elements show that Watchmen is at the same time, and at least, a alternative history ("une uchronie" in french), a parody and a metafiction. To expose the fictional layers and the different aspects of the structure is easy, but to describe the process of the fiction, how it is built and how the reader relate to it, is more difficult. Yet, in its own way, the story tells us how to deal with it: it gives readers a clue with the re-election of Nixon, which alludes to Saul Kripke's example when he explains the concept of a possible world through alternative history. Kripke says that a parallel or possible world is opened by a trivial counterfactual such as "If Nixon had lost the election in 1968...". In Watchmen, one of the divergence points from the actual world opening the fictional world is: "If Nixon didn't have to resign in 1974 ...". Besides, as Jean-Michel Salanskis pointed out in one of his articles, "Fiction des mondes", one the tendencies of the science fiction is to focus on the transition to a parallel universe $^{5}$ - which is obviously the case with Moore's graphic novel. Combining these two points invites us to explore transworld travel in the Watchmen through the literary theory of possible worlds.

Describing the structure of Watchmen's world, how this structure refers to many other worlds, and the visual and textual devices which set it up, will explain how graphic narratives can build reference to different worlds (and relations between them) and give the reader access to worlds that are symbolically, logically or ontologically different from the actual world. This first step will lead me to consider the reading of Watchmen as a way of entering the world of the history of comics, since Watchmen is building a fictional world through narratives and characters deducted from textual phenomenons. I will end with some semantic implications of this pragmatic conclusion, as the comic book is a critique of the superhero figure and the political order it is attached to.

\section{Watchmen's worlds: multi-reference and combination of fictional genres}

To expose and explore the map of Watchmen's fictional worlds, the suggestions of Françoise Lavocat in "Les genres de la fiction" works particularly well. She extends the notion of recentering of the reader in the world projected by the graphic novel, proposed by Marie-Laure Ryan 7 , by the "objectivization" of this world: in other words, the world projected by the comic is the one to which the other possible worlds (actual/real and fictional) relate; it is considered as the starting point to travel to the other possible worlds. It is a way of understanding how this fiction works.

\footnotetext{
3 As it happens in the comic genre, the superheroes unified in a team which took the name of "Crimebusters", after another generation called "the Minutemen".

$4 \quad$ Kripke (1980, esp. p. 40-49)

5 Salanskis (2003-2008).

6 Lavocat (2010).

7 Ryan (1991).
} 
In fact, as Thierry Groensteen has showed ${ }^{8}$, the panels are like fragments of the world in which the story develops, but this world is supposedly homogenous, consistent and complete; so once the reader has entered it through the picture which opened it for him, he doesn't get out of it. He's helped in this by the visual structure of the comic, which is a succession and at the same time a coexistence of the pictures: he has in front of him a panoptical display of pictures which relate metonymically to the world projected by the book. And, as I will explain, the reader is visually taken from this world to other worlds the picture can refer to, with very economical devices of superposition - these devices being of visual and textual nature; as a result, Watchmen can be seen as a combination of fictional genres.

The world of Watchmen refers to, or rather, is related to other fictional worlds (superheroic, science-fictional, and counterfactual or alternative) and to the actual world. As a consequence it gives the readers an access to them ${ }^{9}$. As the next typology will show, each of these worlds is accessed through one mind operator - a powerful operator of fiction - which can be put as follows: "what happens if we take the superhero figure seriously?".

The first and most obvious one is the world of superhero comics. The first pages set the action in contemporary New York - that is, considering the date of the publication, mideighties New York - and for the reader it is at the same time clearly a superhero comic book, giving access to the superhero universe. The body of Edward Blake, who was The Comedian, has been discovered by the police, and at night an anonymous human figure gets into his apartment. There are many references to the superheroic genre (fig. 2): the "regular frame", with symmetric cut-out of the figures; the saturated colours; the action of the character, underlined by extremes angles of the perspective, making the panel look like one of Spiderman $^{10}$. Once in the flat, Rorschach opens a secret closet and the display of the superheroic topics continues: the masked hero; the costume (with a direct reference to Captain America) ; the photo of a league, like the ones created during World War II; the hidden identity, which is necessary for an illegitimate watchman of the legitimate $\operatorname{order}^{11}$. All this is not only found in the beginning but is recurrent during all the graphic novel.

The second fictional world Watchmen opens to is of course the world of science fiction, or more exactly the subgenre of futuristic fiction. Here the date of the represented events and of the publication as well has a significant connotation, somewhat ironic: 1985 is very close to 1984 . More generally, the futuristic vision is accessed through the transfer of superheroes into the "real" world: thanks to Dr Manhattan, the progress of technology is such that the world of Watchmen is like a world of the future one: the Ozymandias headquarters (IV, 21; XII,26), some of New York architecture, the tools made by Dr Manhattan, the detail of a new kind of cigarette, etc. make it clear for the reader. This is how a comic book series published in 1986 and 1987 can present a story set in 1985 and at the same time belong to the science fiction genre.

Thanks to Dr Manhattan, the Comedian, and to a certain extent the other costumed heroes, Nixon got re-elected and the US is very much like the kind of regime currently depicted in the futuristic genre: a mock republic with a very authoritarian power and ultra violent cities. So Watchmen refers as well to alternative history novels and comics. On the technological side as well as on the political side, the story takes really, that is seriously, into

\footnotetext{
$8 \quad$ Groensteen (1999, p. 13 sqq).

9 As soon as the concept of possible world is accepted, the accessibility On the relation between reference to a coherent world and access to it, see Ryan (1991 and 2010).

$10 \quad$ See John Buscema's advice in Lee and Buscema (1978).

11 All these paraphernalia can be seen on pages 5 and 8 of the first chapter; page 2, a photo shows the Comedian shaking hands with President Ford. From now on, the references to the graphic novel will be given as follow: I,5, or IV,16, the roman number refering to the chapter, the arab one to the page of the chapter, each being numbered by Gibbons at the bottom right. This pagination is therefore the same in all editions.
} 
account the existence of superheroes.

But as alternative historical fiction, it refers to the actual world. First, in a negative way: Lubomir Dolezel points out in his article about alternative fictions ${ }^{12}$ that these narratives make explicit the distance between the order of the real world and the order of the alternative world; it is here underlined for example by the familiar picture of a helicopter in Vietnam out of which Nixon has come out to celebrate victory (II,13). As Salanskis puts it in the article quoted earlier, the qualification of the alternative world as "alternative", or "possible world", leads the reader to focus on the passage from the real to the alternative world: as a result, his mind travels from one world to the other, going back and forth between 1985 in Watchmen and 1985 in the real world ${ }^{13}$. In other words, the alternative world concerns the real world, or "actual world", as F. Lavocat chooses to call it to avoid the confusion with fictional worlds ; and it also refers to the actual world in a positive way.

As in Philip K. Dick's The Master in the High Castle (1962), the world projected in Watchmen is like a false truncated reality, in which our reality tends to appear by intermittence. The context in which the stories of the characters develop is paradoxically quite realistic and historic, and for the reader of 1985, very topical: USSR invades Afghanistan (III,25); East and West start the arms race again, and the nuclear tension is at its peak (III,27). In these examples, the relation is very mimetic, but it can also be metaphoric: the travel of Dr. Manhattan to Mars could be seen as a figuration of the star wars. Or metaleptic: the presence and the role of the costumed adventurers and superheroes in the graphic novel duplicates superhero characters' evolution as well as the periods of success of the superheroic genre in the US - I'll come back to this later on. The alternative world never stops to interfere with, or rather to refer to the actual world, directly or indirectly. For Salanskis, what is at stake in this kind of fiction is to represent an interesting interference between the two worlds, the reader travelling from one world to the other precisely because of this interference.

To complete the map of Watchmen's universe, one should say a word about the other fictional worlds ${ }^{14}$ the reader has access to, when she's reading this graphic novel. It has been said many times that what also makes this comic book such an impressive work are the different narrative levels, their combination and the way they echo each other. Alan Moore said, fifteen years after the book's publication: "It's tailor-made for a university class, because there are so many levels and little background details and clever little connections and

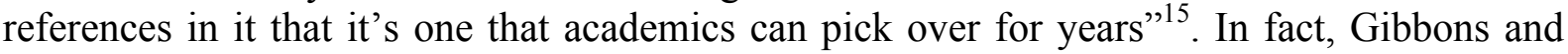
Moore make extensive use of the simultaneous display that the graphic novel authorizes as a sequential and visual art, the "spatio-topical" system as Groensteen puts it ${ }^{16}$.

The panels do not always represent the events of 1985, there are a lot of flashbacks, and the reader has access to the past through different means. Sometimes it is memories of one of the characters, at a funeral for example (II,9-12: Adrian Veidt and Dr Manhattan in front of the Comedian's tumb; fig. 1); sometimes, it is the story told to a journalist (III,5), or to a psychiatrist (IV,3-4). Usually the passage from present to past is provided by a continuity in the design (the frame of the panel, the same element - with a difference - in two consecutive frames) and by a subtle play with the focus ${ }^{17}$.

\footnotetext{
$12 \quad$ Dolezel (2010).

The travel metaphor is also used by Salanskis (2003-2008).

Following Ryan, I use the notion of possible worlds in a large sense.

Moore (2000).

Groensteen (1999, p. 21 sqq).

The pictures may contradict the story told by a character. To understand all the means graphic narratives have for presenting minds in action, see Mikkonen (2008). Mikkonen demonstrates how comics "stimulate the viewer's engagement with the minds of characters by recourse to a wide range of verbal modes of narration in a dynamic relation with images that show minds in action" (p. 302).
} 
The reader has also access to the mind or to the point of view of a character through the way images are sometimes connected and for some of them through their journal: this is the case for the psychiatrist of Rorschach, and for Rorschach himself, the "voice" of the character being signaled by the specific form and colour of the balloon. Hollis Mason's autobiography, Under the Hood, of which some long excerpts are inserted in the comic (I,2732; III,29-32), or Dan Dreiberg's article about owls (VII,29-32), have to be added to theses examples of characters' worlds.

Lastly, there is a comic inside the comic, a pirate story embedded in the story of the superheroes. It is read by a young black guy, who sits next to a newsstand, at a corner where all the characters pass by. It is a kind of fantastical horror comic, which tells how the only survivor of a shipwreck gets home to save his family but, becoming mad, kills them. The ways in which the fictional world of this comic relates to those of Watchmen are several: it can be seen as an allegory of the main narrative (the shipwreck representing the actual situation, generally and individually); there are mimetic and symbolic echoes between the survivor and the characters (for example Dr. Manhattan's loneliness); and it works as a "mise en abyme", or at least as a way of reflecting the poetics of Watchmen: a fake article about the pirate comic can be read as a diary of the writing/drawing of the graphic novel $(\mathrm{V}, 29-32)^{18}$.

From the analysis developed here and the chart established by F. Lavocat ${ }^{19}$, we can see that Watchmen is a combination of fictional genres, and draw a few remarks. It partakes of the main three genres she identified: it is a transfiction, because it is a parodic pastiche of superhero comic, partly metaleptic; it is a "fiction alternative", because it is an alternative history, which turns into a utopia; it is an autonomous fiction as well: someone with some practice in reading comics can inhabit this world, with the help of characters' development, fake articles, documents or autobiographical extracts one can find at the end of each volume: they explain the context and the essential knowledge about superheroes.

Moore and Gibbons' graphic novel engages the reader in circulating between the worlds it refers to. The Vietnam War with superheroes, Nixon at the Pentagon after the invasion of Afghanistan, Rorschach's memories entwined with words of a diary, the pirate story altenating with dialogs that take place around the newsstand, all these panels function and signify by the relation they imply between all the possible worlds. One particular example is very representative of this meaningful circulation, the picture at the bottom right on page XI,6 (fig. 3): the balloon is from the pirate comic, the hand belongs to the news agent and the picture relates to the dream world of Adrian Veidt, who's going to tell the epic of his life in the next pages. The basic form of the comic, as a genre, which implies an articulation of a diegetic sequence with coexisting panels, is essential in the process. Therefore, even in a minor degree, this engagement of the reader in circulating between possible worlds can be extended to many other graphic narratives ${ }^{20}$.

From a pragmatic point of view, this circulation between the various worlds provokes a paradoxical movement: it tends to submerge the reader, caught in a maze, but at the same time, showing him the workings of the comic art, it never lets him forget that it is fiction. Moreover this device which makes the reader going to one world to another is a vehicle of meaning: for example in the first pages, the juxtaposition of the Comedian's murder with the police investigation is ironic, underlining the fall of the superhero instead of showing his achievement. Elsewhere it shows how lives are connected. More generally, it conveys a tragic feeling by contrasting this proliferation of worlds with the end of the world.

Traveling a lot in (and out of) the possible worlds is also a vehicle of fictionality. As I

$18 \quad$ For further details, see Pasquier and Thouret (2006).

19 Lavocat (2010, p. 29).

20 Again, Mikkonen (2008) tend to support this proposition. 
pointed out, each world opens with a specific meaning of "taking the superhero figure seriously"; so in a way, it is on transfictionality that Watchmen builds its fictionality. In this respect, Moore and Gibbons' graphic novel is very much like early modern fictions; as F. Lavocat has suggested, multireference 21 can therefore be synonymous of a high degree of fiction.

\section{From pragmatics to semantics: entering comics history, deconstructing superheroes and the desire for order}

To elucidate the fictional nature of Watchmen and the way the reader travel from one world to another give the essential clues to Watchmen pragmatics. It is worth exploring a bit more the metapoetic dimension of the comic because this aspect of the book is entirely linked to the way the reader enters the worlds of Watchmen. As Hollis Mason, the first Nite Owl ${ }^{22}$, said in his autobiography, "the superheroes had escaped from their four-color world and invaded the plain, factual black and white of the headlines" (I,32); in other words, some people really took seriously the idea of being a superhero. Superheroes have left the fictional world for the real world, but this "real" world is for us a fictional world, partly metafictional.

I already pointed out some similarities between the characters of the comic book and the superheroes who exist in the actual world. Furthermore their destinies resemble those of superhero characters in our world. The first team (The Minutemen) was created in 1938, inspired by the Superman comic, which was first published at this date in the actual world as well as in Watchmen. They have an intense activity during the 40's and especially during World War II before the team is disbanded: this corresponds with what is called the Golden Age in comics history ${ }^{23}$. A second team (The Crimebusters) appears in the 60's, and then is banned by the Keene act: this refers to the revival of superheroes and to the consequences of the offensive against comics, for instance the book of Fredric Wertham, Seduction of the Innocent. Finally, they are US government agents: in the actual world, superheroes played their role in patriotic propaganda.

Thus, what happens is that the Watchmen reader enters the world of comics history. Phenomenons of the art field (for instance the birth, blooming and decline of a genre), described and explained through discourse in academic books, become a narrative with characters and things happening to them. Gibbons and Moore graphic novel is like a realistic novel in which there are shepherds writing poetry (like in pastorals) but they are reduced to misery because everyone is interested in robots, or like a novel set in the 30 's in which the flamboyant adventurer (like in tales of chilvalry) struggles to find exploits to achieve. From this we can see that the nature of the relations between possible worlds determine the way the reference is built up, and the way the reader gets into the world projected by the book.

Since the reader has the same relation to superheroes as the characters of Watchmen (admiration of or identification with fictional entities), he is on the same ground as them and he is invited to understand the history of superhero comics from the inside, with its motivations and its issues. As I wrote earlier, the alternative world built on the counterfactual proposition is paradoxically close to the actual world (the USSR invade Afghanistan, The Madison Square Garden is the venue of rock concerts). The meaning of this closeness or resemblance is quite literal: if superheroes existed, the world would not be radically different;

\footnotetext{
21 There is multireference (or «polyréférentialité ») when a fiction refers to, or defines, more than one possible world. For instance, allegory is very much characterised by multireference ; the Roman de la Rose refers to : a garden promenade, a love quest, the Bible, Ovid's Metamorphosis, which are fictional worlds, and also to the actual world. Lavocat (2010, p. 26-31).

22 The Nite Owl is the superhero identity Hollis Mason gave himself in the fourties; after Mason retired, Dan Dreiberg, one of the main character of the graphic novel, took the same superhero character, becoming thus the second Nite Owl. See next paragraph.

23 Gabilliet (2005, p. 53-69).
} 
they would be condemned to join the strongest side and they would simply reinforce tendancies in militaristic and authoritarian regimes. And the conclusion is clear: the idea of the superhero as a savior is an illusion, it is just a way to incarnate fascistic fantasies and fascination for order.

Yet one of them "saves the world": Adrian Veidt, the smartest and richest man on the planet, imposes peace on earth. He has sent a transgenic monster on New York, killing half of its population but provoking a reunion between the USA and the USSR in the need of a united front against the extra-terrestrial menace. Veidt sees it as the end of History and the instauration of a true utopia. But this new era is only the realization of his own order, something between a capitalistic fantasy and a dream of a man who likes to think of himself as the new Alexander ${ }^{24}$. Besides, the stability of this new order is anything but certain: the last picture of the book leave the reader predicting the publication of Rorschach's diary which will reveal the master plan behind the mysterious catastrophy (he sent the diary to a small patriotic and reactionary newspaper); and, among other parts, the story of Dr. Manhattan and his Mars voyage insists on the fact that life and human history is characterized by chance ${ }^{25}$.

Veidt's character and his plan suggest how much the conspiracy theory inspires the superhero genre and at the same time identify it with a fantasy of power in which the subject desires to be the champion in front of one enemy. As I will show in the next paragraphs, this fascination for order is contradicted by Watchmen in a very practical way, through the ambiguity and weakness of some of its characters (Dreiberg, Laurie, Rorschach, even the Comedian) and through the comic dispositif, its visual structure preventing by its complexity the building of a unique point of view which allows to put things "in the right order".

If we take Rorschach for instance, all his ideology, all his action, at least the way he thinks about it, is governed by the radical difference between the good and the evil he believes in - as his mask metaphorically shows, never mixing the black and white in the Rorschach pictures it creates (see fig. 4). On the contrary, the reader can never really decide what he or she thinks of this character or feels towards him and his behaviour: sympathy because of what happens to him as a kid, indignation in front of his cruelty and violence, doubts concerning the expeditive justice he uses, pity for his desire of friendship, admiration for the strong fidelity he shows to his fellows. These mixed feelings implicitly but strongly contradict the character's ethics, which are very close to the genre's morals: in the superhero world, even if the hero can sometimes be tempted by evil (and I would be tempted to add: especially in these instances), the opposition between good and evil is always sound. Thus the way the reader relates to Rorschach, that is the ambiguity in the reader's possible reactions to the character, subverts the value system that usually rules superhero comics.

Even more decisive in the questioning of order is the multiplication of fictional worlds. First, the reader has no choice but to travel from one world to another and to circulate a lot between them : it is necessary to understand the panels and in many cases the story. Second, Moore and Gibbons rely on this plurality of worlds to almost loose him or her: they have added a large number of visual or discursive echoes and symmetric patterns between the storylines and the different worlds. This "cristalline structure", as Moore called it, prevents the construction of a unique point of view, or of a strict linearity; consequently the multiplication of worlds undermines the possibility or the idea of order.

But it is not all deconstruction. Watchmen is more like an "anti-scenario" or a

\footnotetext{
24 His costume as a superhero is inspired by the great conqueror and he puts it back on at the end of the story; their are plenty texual and pictural references to Alexander's history.

25 Paik's interpretation (2010, chap. 1 "Utopia achieved. The Case of Watchmen", p. 23-69) is completely opposite to mine; he argues that the plan is bound to succeed, since even The Comedian believes in it. But the monster is too ridiculous and too far from Gibbons imagery not to be ironic; moreover it directly contradicts Moore political discourse as we will see further down.
} 
“counter-outline", to translate Yves Citton's "contre-scénarisation"26. Beyond Veidt's idea of the future, other characters' destinies can be read as possible horizons: the new world Dr. Manhattan wants to create on another planet, the couple Dan and Laurie make up together - a new version of Adam and Eve. Above all heroism is not completely discarded, even if it flirts sometimes with madness. Trouble comes if one takes heroism too seriously: this is what happens to the protagonists. Through their superhero identities and characters, Dan Dreiberg, Edward Blake, Walter Kovacs, Adrian Veidt choose a role to play in their own life: Nite Owl, The Comedian, Rorschach and Ozymandias; but they do it too seriously, and the last three become their costume, losing most of their reason in the process (V,28; XII,19; fig. 4).

These last considerations are specific to Moore and Gibbons' comic book, but as far as the construction of possible worlds and the reader's transportation into the worlds of the comic are concerned, Watchmen can be seen not only as an example but also as a model. Because it explores the art form in its content as much as in its forms, it can be used as an example to show how graphic narratives work, or at least could work. Three propositions in this perspective will then serve as a conclusion. First of all, the metaleptic operator "What happens if we take the superhero figure seriously?" is the starting point or the door which opens onto the different worlds of Watchmen: operator could be transposed in other comic genres to elaborate graphic novels and fictions of the same kind. Secondly, Watchmen suggests that in graphic narratives strong narrativity, or high investment of the reader in narrative tension, can be compatible with intense circulation between worlds. Lastly, as we have seen, the multiplication of worlds, their superposition and the different ways they relate to each other is a factor of fictionality and, at the same time, of reference to the actual world and I would choose to see this last proposition as an encouragement to readers to inhabit as many possible worlds as possible.

26 Citton (2010, “Introduction. "Doux pouvoir" et scénarisation”) 


\section{Reference list}

Citton, Yves. 2010. Mythocratie. Storytelling et imaginaire de gauche. Paris: Éditions Amsterdam.

Dolezel, Lubomir. 2010. Récits contrefactuels du passé. In La théorie littéraire des mondes possibles, ed. Françoise Lavocat. Paris: CNRS Éditions.

Gabilliet, Jean-Paul. 2005. Des Comics et des hommes. Histoire culturelle des comic books aux Etats-Unis. Nantes: Éditions du Temps.

Gibbons, Dave and Moore, Alan. 1987. Watchmen [1986-1987]. London: Titan Books.

Groensteen, Thierry. 1999. Système de la bande dessinée. Paris: PUF.

Kripke, Saul A. Naming and Necessity. 1980. Cambridge, Massachusetts: Harvard University Press.

Lavocat, Françoise. 2010. Les genres de la fiction. État des lieux et propositions. In La théorie littéraire des mondes possibles, ed. Françoise Lavocat, 15-51. Paris: CNRS Éditions.

Mikkonen, Kai. 2008. Presenting Minds in Graphic Narratives. Partial Answers 6/2: 301-321.

Moore, Alan. 2000. The Alan Moore Interview, Interview of Barry Kavanagh with Alan Moore, $17^{\text {th }}$ october 2000. Blather: http://www.blather.net/articles/amoore/watchmen3.html. Accessed 28 Sept 2011.

Paik, Peter Yoonsuk. 2010. From Utopia to Apocalypse. Science Fiction and the Politics of Catastrophe. Minneapolis: University of Minnesota Press.

Pasquier, Renaud and Thouret, Clotilde. 2006. Watchmen, à deux voix. Labyrinthe 25: 69-82. http://labyrinthe.revues.org/index1409.html. Accessed 28 Sept 2011.

Ryan, Marie-Laure. 1991. Possible Worlds, Artificial Intelligence and Narrative Theory. Bloomington: Indiana University Press.

Ryan, Marie-Laure. 2010. Cosmologie du récit. Des mondes possibles aux univers parallèles. In La théorie littéraire des mondes possibles, ed. Françoise Lavocat, 53-82. Paris: CNRS Éditions.

Saint-Gelais, Richard. 2011. Fictions transfuges. La transfictionnalité et ses enjeux. Paris: Editions du Seuil.

Salanskis, Jean-Michel. 2003-2008. Fiction des mondes. Alliage 60.

http://www.tribunes.com/tribune/alliage/60/Salanskis.html. Accessed 28 Sept 2011.

Buscema, John and Lee, Stan. 1978. How to Draw Comics the Marvel Way. Simon \& Schuster. 


\section{Figure list}

Fig. 1: Watchmen, chap. II "Absent Friends", p. 9.

Fig. 2: Watchmen, chap. I “"At Midnight, All The Agents..."”, p. 5.

Fig. 3: Watchmen, chap. XI "Look on My Works, Ye Mighty...", p. 6.

Fig. 4: Watchmen, chap. V "Fearful Symmetry", p. 28. 